\title{
Maize Yield Affected by Periods of Weed Interference in Southern Guinea Savannah Zone of Nigeria
}

\author{
Tanimu MU1", Adeosun $\mathrm{JO}^{2}$, Muhammad A' ${ }^{1}$, Na Allah MS', Bubuche $\mathrm{TS}^{1}$, Ardo AM ${ }^{3}$, Yusuf $\mathrm{H}^{4}$, Tiamiyu RA \\ ${ }^{1}$ Faculty of Agriculture, Department of Crop Science, Kebbi State University of Science \& Technology, Aliero, Kebbi State \\ Nigeria \\ ${ }^{2}$ Faculty of Agriculture, Department of Crop Science, Federal University Dutsin-ma Katsina State, Nigeria \\ ${ }^{3}$ Department of Forestry, College of Agriculture Zuru, Kebbi State, Nigeria \\ ${ }^{4}$ Lecturer II, Department of Preliminary Studies, College of Science and Technology, Waziri Umaru Federal Polytechnic, \\ Birnin Kebbi, Kebbi State, Nigeria \\ ${ }^{5}$ Department of Crop Science, Faculty of Agriculture, Usmanu Dan Fodiyo University Sokoto Sokoto State, Nigeria
}

*Address for Correspondence: Tanimu Musa Umar, Lecturer 1, Department of Crop Science, Faculty of Agriculture, Kebbi State University of Science and Technology, Aliero, Nigeria

E-mail: musa.umartanimu@ksusta.edu.ng

Received: 26 Apr 2018/ Revised: 15 Mar 2020/ Accepted: 23 May 2020

\begin{abstract}
Background: Maize is an important crop for resource poor farmers across Africa and Asia. The crop is susceptible to weeds that severely reduce yields, because of their competition with the crop for moisture, nutrients, sunlight and space.

Methods: A regression analysis was carried out to find the association between maize grain yields and weed dry matter production. The predicted values of total maize grain yield and weed dry matter production was obtained using the equation $Y=a$ $+b_{1} z+b_{2} z^{2}, Y$ is maize grain yield/weed dry matter production and $z$ is a function of time of weeding such that the slope is zero at $z=0$ (time of sowing) and $z^{2}=12$ (time of final harvest) $b_{2}$ is the regression coefficients.

Results: The result showed rapid growth of weeds between 3 and 6 weeks after sowing (WAS), while the initial period of weed competition with improved maize varieties lies between 3 and 6 WAS. The crops kept weed free initially for 20 and 42 days after sowing had yield reduction of about 65 and $50 \%$, respectively. Plots infested for 63 and 84 days had an estimated yield loss of 88 and $93 \%$. Initial weed infestation for 42,60 and 91 days after sowing had yield reduction of 20,30 and $60 \%$.

Conclusion: The most critical period of weed competition with the crop was between 6 and 9 WAS. Plots weeded subsequently after initial infestation of 70, 50 and 22 days after sowing had estimated 10, 20 and $50 \%$ reduction of weed growth respectively.
\end{abstract}

Key-words: Gidan Kwano, Maize varieties, Southern Guinea Savannah, Susceptible, Weed interference

\section{INTRODUCTION}

Maize production in Nigeria was initially restricted mainly to the forest zone but the production has now expanded to the savannah where it accounts for over $70 \%$ of the production in the country according to Uyovbisere ${ }^{[1]}$. Higher production of the crop in the savannah was attributed to more favorable production conditions, which include solar radiation intensities, lower night temperature and low incidence of diseases

\footnotetext{
How to cite this article

Tanimu MU, Adeosun JO, Muhammad A, Na-Allah MS, Bubuche TS, et al. Maize Yield Affected by Periods of Weed Interference in Southern Guinea Savannah Zone of Nigeria. SSR Inst. Int. J. Life Sci., 2020; 6(4): 2601-2611.
}

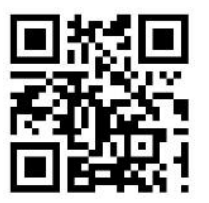

Access this article online https://iijls.com/ and pests as observed by Kassam et al ${ }^{[2]}$. Maize is a cereal plant that produces grains that can be cooked, roasted, fried, ground, pounded or crushed to prepare various food items like pap, tuwo, gwate, donkunu and a host of others as reported by Abdurrahman ${ }^{[3]}$. All these food types are readily available in various parts of Nigeria among different ethnic groups which are Hausas, Yorubas, Ibos, Ibiras, Ishas, Binis, Efiks and Yalas etc as reported by Osagie and Eka ${ }^{[4]}$. The major weed of maize in Nothern Nigeria is Striga it has been reported that: "in the Nigerian Savannah weed related yield losses ranges from $65-92 \%$ has been recorded" according to FAO ${ }^{[5]}$. Striga causes estimated cereal grain losses of up to N1, 050.00 billion as observed by IITA ${ }^{[6]}$. This affects the lives of about 300 million people according to IITA ${ }^{[6]}$. Other constraints to maize production in the maize growing 
areas of sub-Saharan Africa are downy mildew, rust, leaf spot, and maize streak virus, other pests include insects namely: stem and ear borers, armyworms, cutworms, grain borers, and rootworms as reported by IITA ${ }^{[6]}$.

Hoeing is the cultural method adopted for weed control in cereals of which maize is inclusive in the southern guinea savannah zone. Hoeing is laborious, slow, expensive and only feasible on a smallholding, as observed by David et al. ${ }^{[7]}$ and Adeosun ${ }^{[8]}$. Some weeds especially those that have close resemblance with the maize crop at the young stage e.g. Andropogon gayanus, however escape weeding; these will compete with maize seriously and will cause reduction in yield considerably. Hand weeding using hoe is beneficial to the maize crop because it tends to improve aeration in the soil environment as observed by Adeosun ${ }^{[9]}$. For the hoe weeding to be successful, proper timing and frequency of weeding are necessary. Weeds pose a problem to the growth, development and yield of the maize crop. Like in other crops, weeds compete with maize for sunlight, water, nutrients and space. The extent of the competition depends on the rate of growth of the weeds, their growth habit, their density and time at which they start to grow relative to the crop according to Matthew ${ }^{[10]}$. The density of weeds, relative to that of the crop will have an influence on the degree of onset of competition as reported by Matthew ${ }^{[10]}$. It is however interesting to note that most studies on the weed interference in maize in the guinea savannah zone of Nigeria have not taken into account the reaction of different varieties to weed competition. The new varieties used for his study are tall growing (especially the hybrid variety) and drought resistant, which will enable them to form canopy to suppress the weeds and escape drought. Hence the need for this study to compare the four maize varieties and investigate their reaction to different weed competition at various periods in this ecological (Southern guinea savannah) zone of the country. The objective of this study was to assess four maize varieties to ten periods of weed interference and also to assess the susceptibility of the maize varieties to the effects of weed growth on grain yield.

\section{MATERIALS AND METHODS}

Study area- Field trials were conducted during the raining seasons of 2011 and 2012 at the Research Farm of the Federal University of Technology Gidan kwano campus Minna (latitude $9^{\circ} 41^{\prime} \mathrm{N}$ and longitude $6^{\circ} 31^{\prime} \mathrm{E}$; $258.5 \mathrm{~m}$ above sea level) in the southern Guinea savanna zone of Nigeria. The climate of Minna is sub-humid with mean annual rainfall of about $1284 \mathrm{~mm}$ and a distinct dry season of about 5 months duration occurring from November to March. The mean maximum temperature remains high throughout the year, about $33.5^{\circ} \mathrm{C}$ particularly in March and June as reported by Ojanuga [11] in the Southern Guinea Savannah zone in the Niger State of Nigeria.

Treatments and Experimental design- The treatments were laid out split plot arrangement in randomized complete block. These were made into maize varieties (early, extra early \& a late maturing or hybrid) and ten periods of weed interference. One set of the interference treatment; plots were kept initially weedfree for 3, 6, 9 and 12 WAS maize and subsequently left un-weeded. In the other set of treatments, plots were left un-weeded for 3, 6, 9 \& 12 WAS but were left weed free until harvest. Two control treatments were maintained in which one plot weed free, while the other plot was left weed infested until harvest in both cases. The treatment consisted of 2 extra early maize varieties, one early variety and one hybrid. The maize varieties tested in this study are: (1) Oba 98; (2) SAMMAZ 13 (Extra early variety); (3) EVDT-Y2000 (Early variety); (4) 2008 DTMA-Y(STR) (Extra early variety).

Cultural practices- The experimental area was cleared ridged and spaced at $75 \mathrm{~cm}$. The field was marked out into plots and replications using measuring tape. Each split-plot (4 mx3.75 m) $15 \mathrm{~m}^{2}$ had six ridges. Seeds were sown manually at the rate of 3 seeds per hole along the ridges at an intra-rows spacing of $50 \mathrm{~cm}$. The plants were thinned to 2 plants per stand at ten days after planting. Weeding using hoe was carried out at 3, 6, 9 and 12 WAS during the season of 2011 and 2012. Basal application of fertilizer by banding method using NPK 15-15-15 was done at the recommended rate of $120 \mathrm{kgN}, 60 \mathrm{kgP}$ and $60 \mathrm{kgK}$ per hectare. Weed fresh weight (using weighing scale balance) was obtained by taking weed samples at random using $1 \mathrm{~m}^{2}$ quadrat in each plot at 3, 6, 9 and 12 WAS. The weed samples were cleaned free of soil and oven-dried at $70^{\circ} \mathrm{C}$ to constant weight, and the dry weight was recorded. Crop growth and yield parameters were taken and recorded according to recommendation (at 3, 6, 9 and 12 WAS). 
Statistical Analysis- Data collected were subjected to analysis of variance (ANOVA) using general linear model (GLM) as described by Snedecor and Cochran ${ }^{[12]}$, and significant means were separated by Duncan's Multiple Range Test ${ }^{[13]}$. Regression analysis was also carried out to determine the association between maize grain yields and cumulative weed dry matter production of predicted values of maize grain yield as related to periods of weed interference with the equation $Y=a+b_{1} z+b_{2} z^{2}$, where $Y$ is maize grain yield/weed dry matter production and $z$ is a function of time of weeding such that the slope is zero at $z=0$ (time of sowing) and $z^{2}=12$ (time of final harvest) $a$ and $b$ are the regression coefficients.

\section{RESULTS}

There was high weed infestation during 2011 season than 2012 and conversely, the crops performed better in 2012 than 2011. The most prevalent grass weeds include Brachiaria deflexa (Schumah), Digitaria sanguinalli, Rottboellia cochinchinensis and Andropogon gayanus. The prevalent broad leaf weeds were Fleura aestuans (Linn.), Commelina benghalensis (L.), Sida acuta Polak, Tridax procumbens and Calapogonium muconoides. Cyperus esculentus (L.) and C. rotundus (L.) were the only Sedges prevalent in the fields. The effect of variety on weed dry matter was only significant in 2012 but not in 2011 (Table 1). During 2011, wet season, the weed biomass was higher than in 2012. Weed suppression is shown by weed dry matter; the varieties were not consistent across the two years of the study.
While 2008-DTMAYSTR gave the best weed suppression in 2011, EDTY-2000 gave the best weed suppression in 2012. The effect of the period of weed interference on cumulative weed dry matter was significant in both years (Table 1). Variety $X$ period of weed interference was significant on cumulative weed dry matter (Table 2 ) in all initially weed-infested and those of weed-free plots during the 2011 wet season. The result of the effect of variety on grain yield was significant only in 2011 (Table 3). Variety 2008-DTMA-YSTR had the highest grain yield in 2011 with a value of $3.77 \mathrm{t} / \mathrm{ha}$ (Table 3) followed by Sammaz-13 (2.71 t/ha), next was EVDT Y-2000 (2.57 $\mathrm{t} / \mathrm{ha}$ ) and Oba-98 (2.25 t/ha) had the least grain yield value during the 2011 wet season. Period of weed interference significantly affected grain yield in both years. The grain yield was decreased as plots were kept initially weed-infested beyond 3WAS till harvest during 2011 and 2012 wet seasons. As the plots were initially kept weed-free the grain yield increased from a minimum value of $1.69 \mathrm{t} / \mathrm{ha}$ and $2.73 \mathrm{t} / \mathrm{ha}$ for 2011 and 2012 to a maximum value of $3.87 \mathrm{t} / \mathrm{ha}$ and $6.47 \mathrm{t} / \mathrm{ha}$ for 2011 and 2012, respectively. Weed infestation for 3WAS did not significantly affect the grain yield throughout the study. However, infestation beyond 6WAS drastically reduced the grain yield compared with the initial weed free periods from 9WAS till harvest. There was no significant interaction between variety and period of weed inference on grain yield.

Table 1: Effect of Variety and Period of weed-interference on cumulative weed dry matter production at Gidan Kwano

\begin{tabular}{ccc}
\hline Treatments & \multicolumn{2}{c}{ Cumulative weed dry matter (t/ha) } \\
\cline { 2 - 3 } & $\mathbf{2 0 1 1}$ & $\mathbf{2 0 1 2}$ \\
\hline Variety (V) & 1.72 & $0.37 \mathrm{~b}$ \\
Oba-98 & 1.61 & $0.33 \mathrm{~b}$ \\
Sammaz-13 & 1.47 & $1.58 \mathrm{a}$ \\
EVDT Y- 2000 & 1.35 & $0.35 \mathrm{~b}$ \\
2008-DTMA YSTR & 0.35 & 0.34 \\
SE \pm & & \\
Period of Weed-interference (W) & $0.55 \mathrm{~d}$ & $0.28 \mathrm{~b}$ \\
Weed Infested for 3 WAS & $0.62 \mathrm{~cd}$ & $0.44 \mathrm{~b}$ \\
Weed Infested for 6WAS & $3.21 \mathrm{a}$ & $0.45 \mathrm{~b}$ \\
Weed Infested for 9 WAS & $3.39 \mathrm{a}$ & $0.48 \mathrm{~b}$ \\
Weed Infested for 12 WAS & $3.52 \mathrm{a}$ & $3.36 \mathrm{a}$ \\
Weed Infested till harvest & $1.53 \mathrm{~b}$ & $0.44 \mathrm{~b}$
\end{tabular}




$\begin{array}{ccc}\text { Weed free for 6 WAS } & 1.10 \mathrm{ba} & 0.39 \mathrm{~b} \\ \text { Weed free for 9WAS } & 0.63 \mathrm{~cd} & 0.34 \mathrm{~b} \\ \text { Weed free for 12 WAS } & 0.42 \mathrm{~d} & 0.25 \mathrm{~b} \\ \text { Weed free till harvest } & 0.40 \mathrm{~d} & 0.18 \mathrm{~b} \\ \mathrm{SE} \pm & 0.14 & 0.22 \\ \text { Interaction }(\mathrm{VxW}) & * * & * * \\ \end{array}$

WAS= week after sowing.

Means followed by the same letter ( $s$ ) along the column are not significantly different at $5 \%$ level of probability (DMRT)

NS =Not significant, *Significance at $5 \%$ level of probability, ${ }^{* *}$ Significance at $1 \%$ level of probability

Table 2: Variety $X$ period of weed interference Interaction on cumulative weed dry matter at Gidan Kwano during 2011 wet season

\section{Variety \\ Oba-98 Sammaz-13 EVDTY-2000 2008-DTMAY \\ (weed dry matter $\mathrm{kg} / \mathrm{ha}$ )}

\section{Period of weed-interference}

Weed Infested for 3 WAS $^{1}$

Weed Infested for 6 WAS

$0.16 \mathrm{e}$

$0.27 d$

$0.12 \mathrm{e}$

$0.24 d$

Weed Infested for 9 WAS

$0.21 \mathrm{~d}$

$0.29 \mathrm{~d}$

$0.24 d$

$0.37 \mathrm{c}$

Weed Infested for 12 WAS

$0.45 b$

$0.46 \mathrm{~b}$

$0.48 \mathrm{~b}$

$0.43 c$

Weed Infested till harvest

$0.54 \mathrm{~b}$

$0.35 c$

$0.48 \mathrm{~b}$

$0.40 \mathrm{c}$

Weed free for 3 WAS

$0.55 b$

$0.43 c$

$0.60 \mathrm{a}$

$0.36 \mathrm{c}$

Weed free for 6 WAS

$0.50 \mathrm{~b}$

$0.42 \mathrm{c}$

$0.30 \mathrm{~d}$

$0.32 \mathrm{c}$

Weed free for 9 WAS

$0.37 \mathrm{c}$

$0.42 \mathrm{c}$

$0.30 \mathrm{~d}$

$0.34 \mathrm{c}$

Weed free for 12 WAS

$0.50 \mathrm{~b}$

$0.39 \mathrm{c}$

$0.18 \mathrm{e}$

$0.45 b$

Weed free till harvest

$0.27 d$

$0.18 \mathrm{e}$

$0.23 d$

$0.33 c$

$0.13 \mathrm{e}$

$0.09 \mathrm{e}$

$0.24 d$

$0.26 \mathrm{~d}$

$$
\mathrm{SE} \pm
$$

0.22

Significance level

Interaction (VxW)

WAS= week after sowing.

Means followed by the same letter ( $s$ ) along the column are not significantly different at $5 \%$ level of probability (DMRT)

Table 3: Effect of Variety and Period of weed- interference on grain yield at Gidan Kwano for 2011 and 2012 wet seasons

\begin{tabular}{lll}
\hline Treatment & \multicolumn{2}{c}{ Grain yield (t/ha) } \\
& $\mathbf{2 0 1 1}$ & $\mathbf{2 0 1 2}$ \\
\hline Variety (V) & & \\
Oba-98 & $2.25 \mathrm{~b}$ & 4.38 \\
Sammaz-13 & $2.71 \mathrm{~b}$ & 3.83 \\
EVDT-Y2000 & $2.57 \mathrm{~b}$ & 4.23 \\
2008DTMA-YSTR & $3.77 \mathrm{a}$ & 4.23 \\
SE \pm & 0.21 & 0.25 \\
& & \\
Period of weed-interference (W) & & \\
Weed Infested for 3 WAS & $3.57 \mathrm{a}$ & $5.95 \mathrm{a}^{2}$ \\
Weed Infested for 6 WAS & $2.51 \mathrm{bc}$ & $4.63 \mathrm{bc}$ \\
Weed Infested for 9 WAS & $2.40 \mathrm{bc}$ & $3.93 \mathrm{dc}$ \\
Weed Infested for 12 WAS & $1.69 \mathrm{c}$ & $2.97 \mathrm{e}$
\end{tabular}




\begin{tabular}{lll} 
Weed Infested till harvest & $1.57 \mathrm{c}$ & $1.79 \mathrm{e}$ \\
Weed free for 3 WAS & $1.69 \mathrm{c}$ & $2.73 \mathrm{de}$ \\
Weed free for 6 WAS & $2.00 \mathrm{c}$ & $3.53 \mathrm{dc}$ \\
Weed free for 9 WAS & $3.59 \mathrm{a}$ & $4.25 \mathrm{bc}$ \\
Weed free for 12 WAS & $3.67 \mathrm{a}$ & $5.41 \mathrm{ab}$ \\
Weed free till harvest & $3.87 \mathrm{a}$ & $6.47 \mathrm{a}$ \\
$\mathrm{SE} \pm$ & 0.33 & 0.41 \\
Interaction $(\mathrm{V} \times \mathrm{W})$ & $\mathrm{NS}$ & $\mathrm{NS}$ \\
\hline
\end{tabular}

1. WAS - week after sowing

2. Means followed by the same letter (s) / are not significantly different at $5 \%$ level of probability (DMRT)

3. NS non-significant

Regression analysis- Fig. 1 to 4 contained curves of predicted values of maize grain yields and total weed dry matter production using the equation $Y=a+b_{1} z+b_{2} z^{2}$, where $Y=$ maize grain yield/ weed dry matter production and $z$ is a function of time of weeding such that slope is zero at $\mathrm{t}=0$ (time of sowing) and $\mathrm{t}=15$ (time of final harvest) $b_{2}$ is regression coefficient. The reconstituted equation in nonlinear form is $Y=a+b_{1} z+b_{2} z^{2}$ according to Salgado ${ }^{[14]}$. The equation gave a relationship of yield / total weed dry matter production and weeding time which has zero slope at both $t=0$ and $t=15$ weeks.
In 2011, the crops kept weed free initially for 20 and 42 days after sowing had yield reduction of about 65 and $50 \%$ respectively. Conversely, plots infested for 63 and 84 days had an estimated yield loss of 88 and 93\% (Fig. 1). Weed reduction of $10,20,50$ and $80 \%$ were obtained on plots weeded at $94,86,60$ and 29 days after sowing respectively (Fig. 2). The most rapid weed growth in 2011 occurred between 3 and 6WAS. Maize variety Oba-98 was critically affected by weed interference between 3 and 6WAS (Table 1).

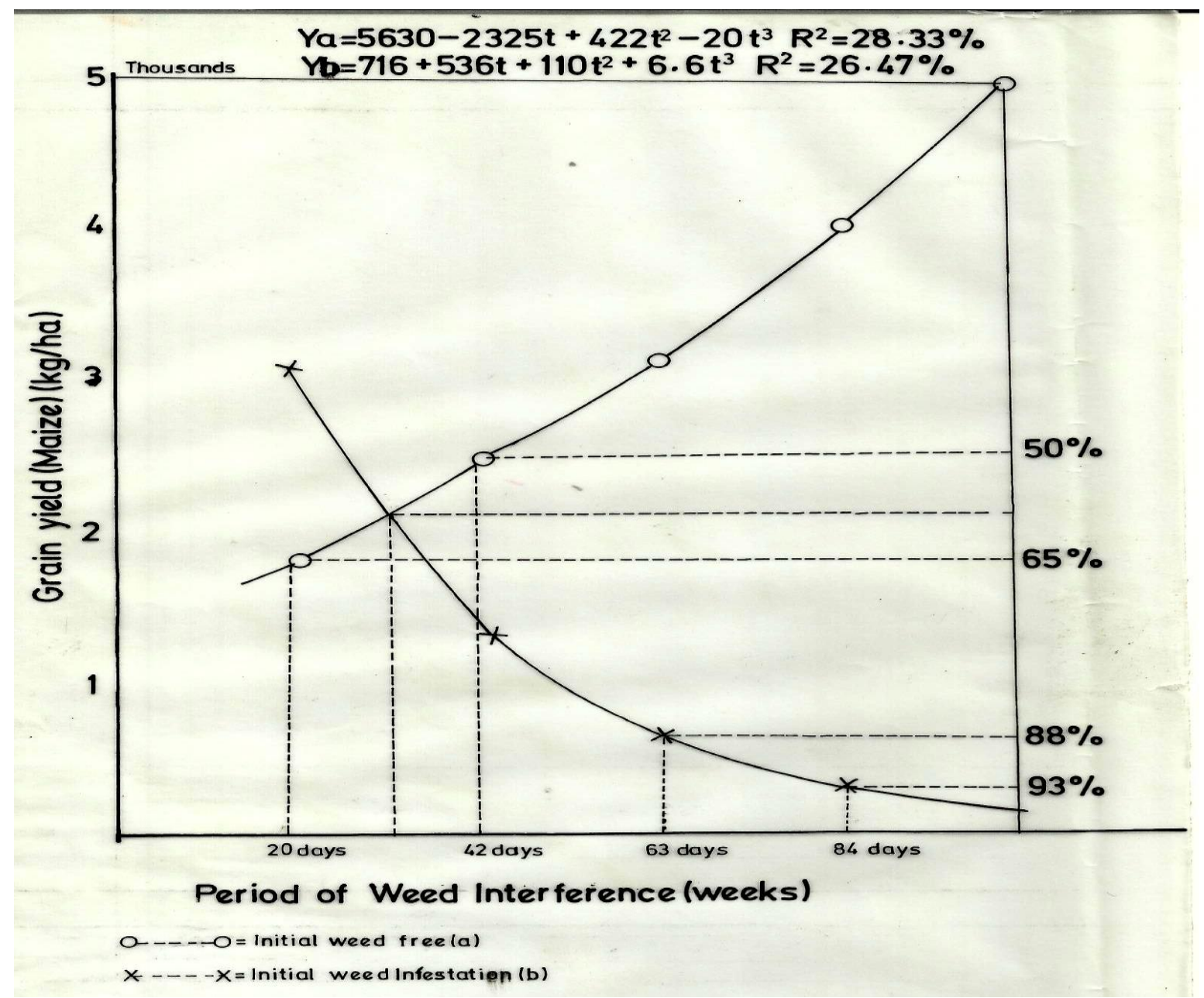

Fig. 1: Fitted values of grain yield (maize) as affected by period of weed interferencen Gidan kwano 2011 


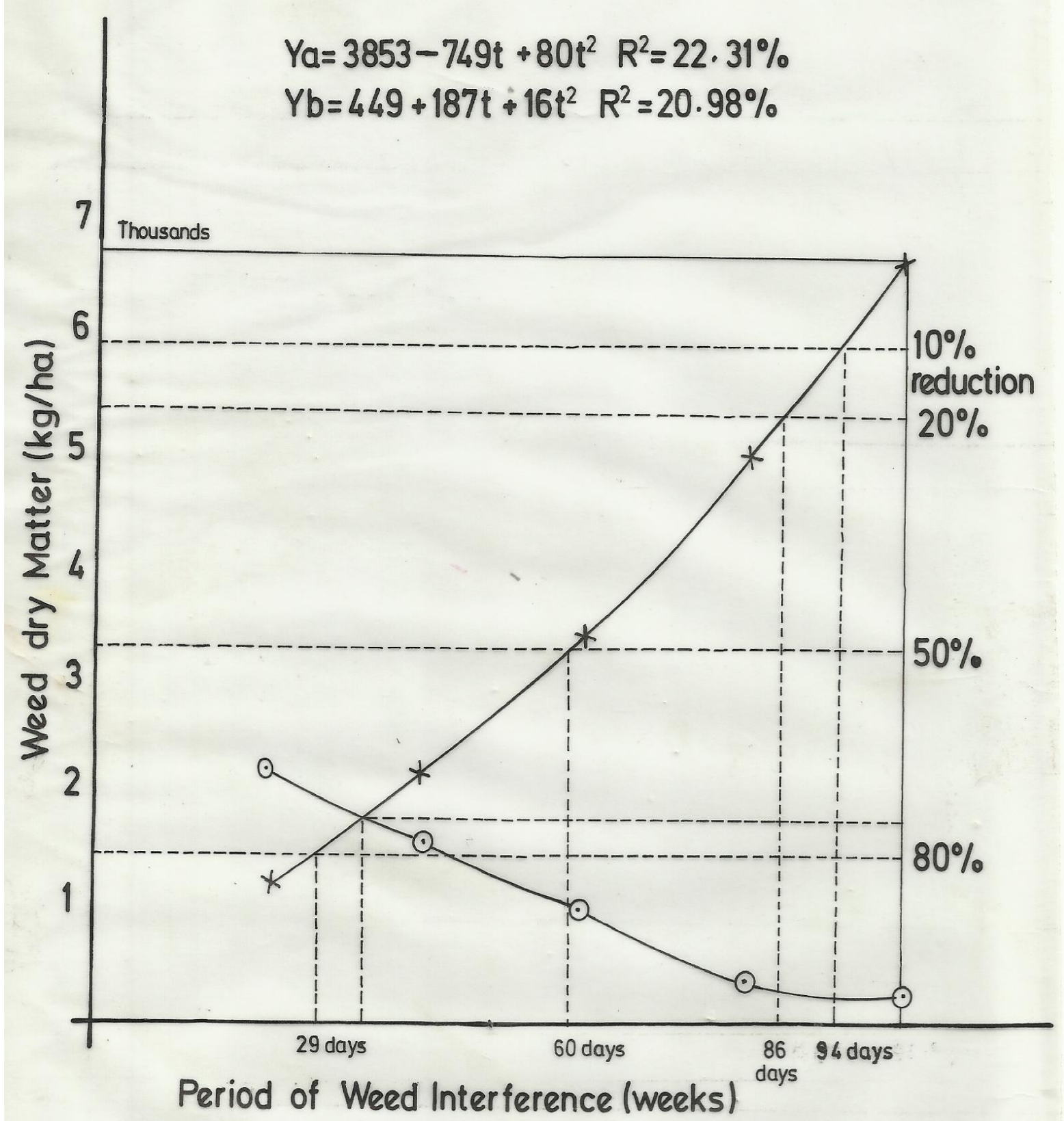

O----o = Inial weed freela)

$x----x=$ Initial weed infestation (b)

Fig. 2: Fitted values of total weed dry matter production as affected by period of weed Interference Gidan kwano 2011

In 2012, crops weed free initially for 91,84 and 40 days after sowing had yield reduction of 8,10 and $50 \%$ respectively (Fig. 3). Initial weed infestation for 42,60 and 91 days after sowing had yield reduction of 20, 30 and $60 \%$ respectively (Fig. 3 ). The most critical period of weed competition with the crop in 2012 was between 6 and 9 WAS (Fig. 3). On the other hand, plots weeded subsequently after the initial infestation of 70,50 and 22 days after sowing had estimated 10, 20 and 50\% reduction of weed growth respectively (Fig. 4).
Although the varieties were on the field for the same period, obvious differences in their growth and subsequent yields were observed. While hybrid variety Oba-98 was initially fast-growing than the other three, at the combined analysis, the variety 2008-DTMAYSTR was most vigorous until the harvest of the other three varieties at the combined analysis. This conformed to the report of Shinggu et al. ${ }^{[15]}$ that showed similar effects on maize varieties tested. 


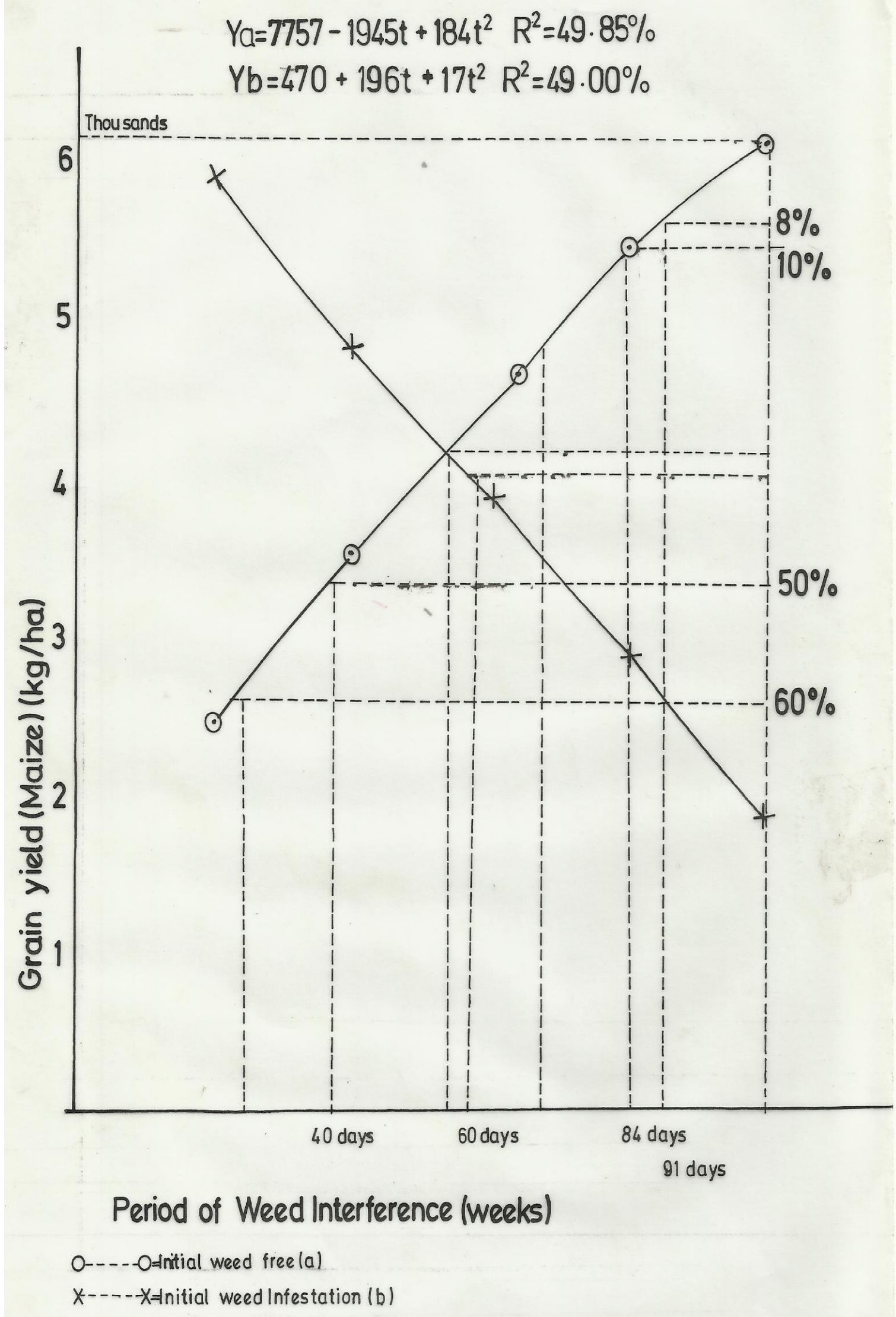

Fig. 3: Fitted values of grain yield (maize) as affected by period of weed interference Gidan kwano 2012 


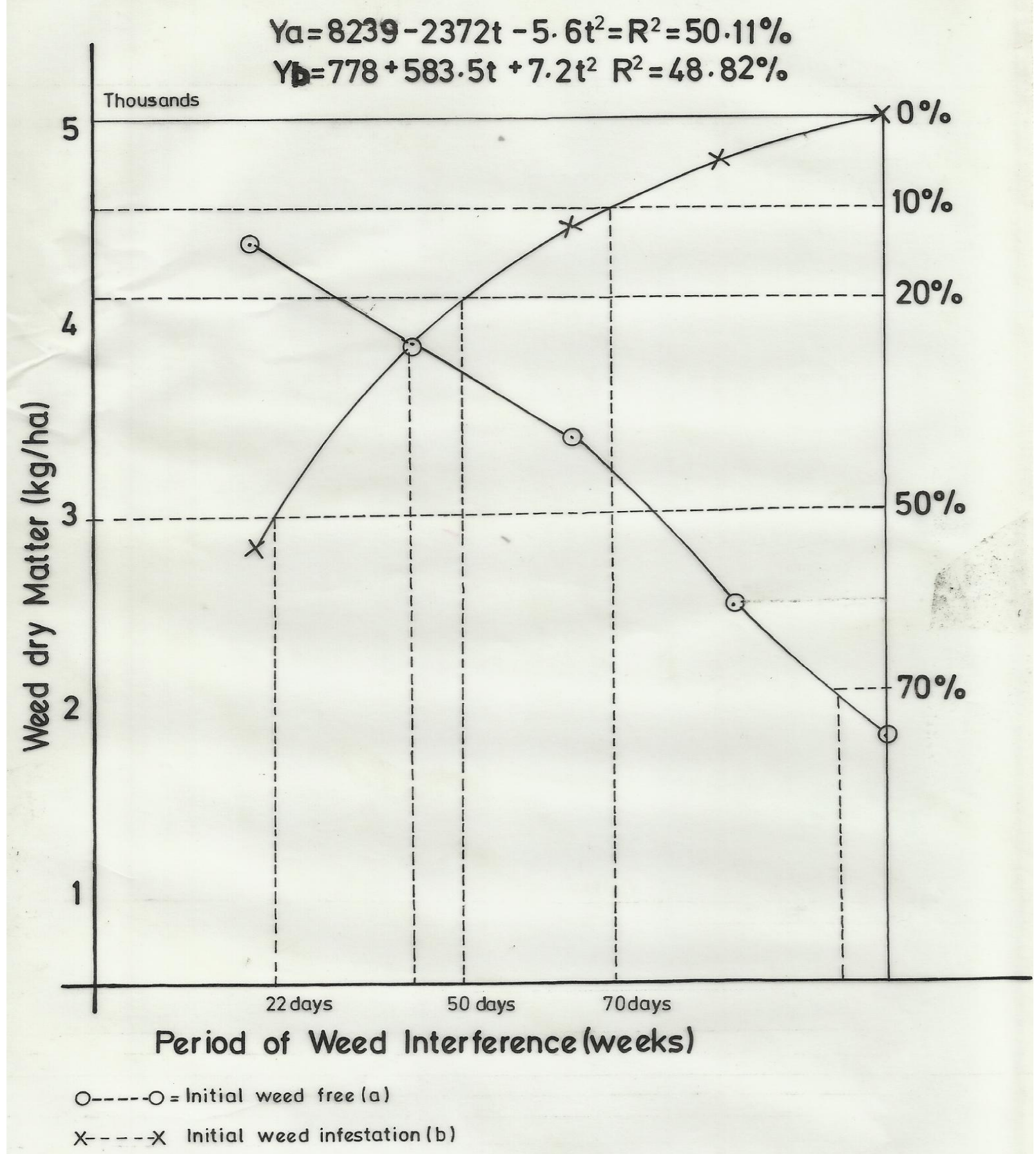

Fig. 4: Fitted values of total weed dry matter production as affected by period of weed Interference Gidan kwano 2012

\section{DISCUSSION}

\section{Performance of Maize Variety and Weed Dry Matter}

Production- Although the varieties were on the field for the same period, obvious differences in their growth and subsequent yields were observed. While hybrid variety Oba-98 was initially fast-growing than the other three, at the combined analysis, the variety 2008-DTMAYSTR was most vigorous until harvest of the other three varieties at the combined analysis.
This conformed to the report of Harika and Bains ${ }^{[16]}$ that showed similar effects on maize varieties tested. The lowest grain yield was obtained with hybrid variety Oba98 during 2011 wet season despite its vigorous growth during the later stage of life-cycle; the grain yields of Sammaz-13 and EVDTY-2000 were similar but higher than that of Oba-98. The reason for this may be since Sammaz-13 is early maturing, adequate grain filling occurred before the cessation of rainfall, which might 
not be the situation with the-late maturing variety oba98, which produced lower grain yield. Oba- 98 was observed to produce highest cumulative weed dry matter among the other varieties this might be as a result of the long slender leaves of the variety which cannot form canopy to smoother weeds to prevent them growing. During 2011 wet season, weed reduction of 10 , 20,50 and $80 \%$ were obtained on plots weeded at 94 , 86,60 and 29 days after sowing respectively while during 2012 wet season, plots weeded subsequently after the initial infestation of 70,50 and 22days after sowing had estimated 10, 20 and $50 \%$ reduction of weed growth respectively. This is attributed to the longer days taken after infestation before control measure were applied hence the less weed dry matter reduction was observed as earlier reported by Travlos ${ }^{[17]}$.

\section{Effect of Period of Weed Interference on the} Performance of Maize- Weed infestation throughout the crop life-cycle decreased the yield of maize variety Oba98 by 65 and $50 \%$ in 2011. Similar yield reductions between 50 and $87 \%$ of maize due to uncontrolled weeds throughout the crop life-cycle were reported by Usman et $a^{[18]}$. Period of weed interference also had a significant effect on crop vigour score at 9WAS during 2012 wet period season. Keeping plots weed free till 9WAS and beyond produced more vigorous crops, while keeping crops weed infested and beyond similar periods, produced less vigorous crops. This might be due to the competition for growth factors between the maize and the weeds in the weed infested plots as reported by IITA ${ }^{[19]}$ and Ferrero et al. ${ }^{[20]}$. Plant height was significantly affected at 9WAS and at harvest for both years. While keeping plots weed free till 9WAS and beyond produced taller crops, the converse was the case when plots were weed infested for the same period. Carson ${ }^{[21]}$ stated that when maize crops were kept weed infested for 9WAS and beyond, their heights significantly decrease. Other yield parameters such as maize cob weight, cob length and weight of 100 seeds were all significantly affected by period of weed interference. Weed infestation from 6WAS and till harvest significantly decreases these yield parameters. In the study, uncontrolled weeds throughout the life cycle of maize varieties resulted in grain yield loss of $59.43 \%$ and $72.33 \%$ respectively for 2011 and 2012 wet seasons compared to maximum obtained with weed free plots throughout the study. Weed infestation for 3WAS only did not significantly affect grain yield of maize in 2011 compared with initial weed free plots at 9WAS, while weed infestation for 3WAS only was comparable to initial weed free plots up to 9WAS. It is apparent that once the crop was kept weed free for 12 WAS subsequent weed infestation until harvest did not cause any significant reduction in maize grain yield in the four varieties. Contrary to earlier reports, weeds infestation for the first 3WAS caused a significant reduction in maize grain yield, even though it did not has an adverse effect on crop growth as reflected in crop vigour score, crop height and weed dry matter production. The yield depression by weed infestation for 3WAS may be attributed to rapid weed growth and its high infestation within 3WAS during the growing season. This was apparent in the weed cover score at 9WAS and beyond. Weed infestation with crop until 12WAS resulted in significantly lower crop vigour score and grain yield compared to infestation for 3WAS. This result agrees with those obtained by Kunjo ${ }^{[22]}$ and Bakut [23], who has similarly reported significant maize yield reduction when weeds were associated with the crop for 6 and 8WAS respectively. Subsequent weed removal until 12WAS did not prevent the reduction in grain yield compared with weed infestation until harvest. Weed dry matter production was higher during 2011 than in 2012. The result showed that maximum maize grain yield was obtained from plot kept weed free for both 2011 and 2012 wet seasons. Variety 2008-DTMAYSTR and EVDTY2000 consistently had a maximum grain yield during the growing seasons. In 2011 wet season, maize plots kept weed free initially for 20 and 42 days after sowing had yield reduction of 65 and 50\%, respectively. However, during 2012 season, maize kept weed free initially for 91, 84 and 40 days after sowing, had yield reduction of 8, 10 and $50 \%$ respectively. This may be as a result of benefits of utilization of nutrients underground according to Sohrab and Ali ${ }^{[24]}$. Result of this study showed that weed infestation at 3WAS did not affect yield of maize. This is supported by Sohrab and Ali ${ }^{[24]}$, which showed that weed infestation untill 3WAS did not affect maize grain yield. Weed infestation for the first 3 weeks did not have any adverse effect on growth and yield of maize, provided that weeds are removed subsequently, according to Takim and Fadayomi ${ }^{[25]}$, who worked on cereal. However, Scott [26] had similarly reported significant positive correlation between maize grain yield vegetative growths as well as negative correlation 
between maize grain yields with weed dry matter. The result obtained indicated that weed interference untill harvest reduced grain yield. Nagaragu and Kumar [27] have similarly reported significant maize yield reduction when weeds were associated with the crop for 6 and 8WAS, respectively. In this study, it was observed in 2011 that period of 21-42 days after sowing is the time when weeds begin to interfere and compete with crops for growth factors. Hence it is the critical period that the weeds exert pressure on maize crop.

\section{CONCLUSIONS}

Among the varieties tested, 2008-DTMAYSTR consistently had the highest yield of 3.77 and $4.23 \mathrm{t} / \mathrm{ha}$ followed by EVDT Y-2000 with yield of 2.57 and 4.23 t/ha, Oba-98 2.25 and 4.38 t/ha and Sammaz-13 2.71 t/ha and $3.83 \mathrm{t} /$ ha for both growing seasons respectively. During 2011 wet season the critical period for weed interference is 35 days after sowing and the corresponding weed dry matter production for this period was $1.80 \mathrm{t} / \mathrm{ha}$ while the critical period that will cause d55significant grain yield is 35 days and the critical grain yield is $2.10 \mathrm{t} / \mathrm{ha}$. During 2012, wet season however, the critical period for weed interference is 42 days after sowing and the corresponding weed dry matter production for this period is $3.90 \mathrm{t} / \mathrm{ha}$; while the critical period that will cause significant grain yield decrease, when weed infestation is not checked i.e. 56 days after sowing, while the corresponding critical grain yield for that period is $4.10 \mathrm{t} / \mathrm{ha}$. Varieties 2008DTMAYSTR and EVDTY-2000 are recommended for cultivation in the study area. A weed free period for the first 35-42 days after sowing is required for optimum grain yield of the improved maize varieties. The critical period of weed interference with maize is between 3 and 6 WAS.

It is expected that more improved or elite maize varieties, when managed under good weed control regimes will lead to the production of higher yield that will be utilized for the teeming population in the study area and beyond.

\section{ACKNOWLEDGMENTS}

The author's area grateful to the Federal University of Technology Gidan kwano Minna, Niger state Nigeria for providing University Teaching and Research Farm and the laboratory which were utilized during the study period. The authors are very grateful to the efforts of the authority of Kebbi State University of Science and Technology Aliero for the support and encouragement.

\section{CONTRIBUTION OF AUTHORS}

Research concept- Adeosun JO

Research design- Tanimu MU, Muhammad A

Supervision- Adeosun JO

Materials- Tanimu MU, Bubuche TS

Data collection- Ardo AM, Na-Allah MS

Data analysis and Interpretation- Tanimu MU

Literature search- Tanimu MU

Writing article- Yusuf $\mathrm{H}$, Bubuche TS

Critical review- Adeosun JO

Article editing- Muhammad A, Tiamiyu RA

Final approval- Adeosun JO

\section{REFERENCES}

[1] Uyovbisere EO, Elemo KA. Effect of tree foliage of locust bean (Parkia biglobosa) and neem (Azadiracta indica) on soil fertility and productivity of early maize in savannah alfisol. Nutr Cycl Agroecosyst., 2002; 62(2): 115-22.

[2] Kassam AH, Kowal J, Dagg M, Harrison MN. Maize in West Africa and its potential in Savanna areas. World Crops, 2005; 27(2): 73-78.

[3] Abdulrahaman AA, Kolawale OM. Traditional Preparations and uses of maize in Nigeria. Retrieved from www.ethnoleaflets.com/kolawole.htm, 2006.

[4] Osagie AU, Eka OU (Eds). Nutritional Quality of Plant Foods. Post harvest Research unit Univ. of Benin, Benin., 1998; pp. 34-41.

[5] FAO. Faosat. Retrieved from http://faosat.fao.org/site/339/default.aspx, 2010.

[6] IITA-Maize. Retrieved from URL http//old.iita$\mathrm{org} / \mathrm{cms} /$ details/maize project, 2009.

[7] David C, Steffen S, Friday E. Evaluation of integrated weed management practices for maize in Northern Guinea savanna of Nigeria. Crop Prot., 23(10): 895900.

[8] Adeosun JO. Valuation of Sowing Date, nitrogen, variety and herbicide for the control of Striga hermonthica (Del) Benth in Sorghum (Sorghum bicolour L. Moench). A Thesis submitted to the department of Agronomy, Ahmadu Bello University Zaria, 1990.

[9] Adeosun JO. Response of upland rice (Oryza sativa L.) varieties to nitrogen, period of weed interference and chemical weed control at Samaru, Nigeria. PhD 
Thesis submitted to the Department of Agronomy ABU Zaria, 1999; pp. 6.

[10]Matthew MH. Effects of shading, relative growth rate and population density on weed responses to nitrogen management in corn. Retrieved from: https://lib.dr.iastate.edu/cgi/viewcontent.cgi?article $=1585 \&$ context $=r t d, 2003$

[11]Ojanuga AG. Agro-ecological Zones of Nigeria Manual.FAO/NSPFS, Federal Ministry of Agriculture and Rural Development, Abuja, Nigeria, 124 pp. In Afolabi, SG, Adeboye, MKA, Lawal BA, Adekanmbi $A A$, et al. Evaluation of Some Soils of Minna Southern Guinea Savanna of Nigeria for Arable Crop Production. Niger J Agric Food Environ, 2014; 10(4): 6-9.

[12]Snedecor GW, Cochran WG. Statiscal methods. $6^{\text {th }}$ Edition, Ames, Lowa, 1967.

[13]Duncan DB. Multiple Ranges and Multiple F-Test. Biometrics, 1955, 11: 1-42.

[14]Salgado TP, Pitelli RA, da Costa AguiarAlves PL. Weed Interference on maize (Zea mays) under no tillage system. J. Environ Sci. Health B., 2005; 40(1): 181-84.

[15]Shinggu CP Dadari SA Shebayan SAY Adekpe DI, Ishaya DB. Effects of Variety crop arrangement and period of weed interference on the performance of maize grown in mixture in Northern Guinea Savannah of Nigeria. Department of Agronomy Faculty of Agriculture Ahmadu Bello University Zaria, Nigeria, 2009; pp. 48.

[16]Harika AS, Bains DS. Studies on weed control in maize fodder India, 2007; 5(1): 13-16.

[17]Travlos IS. Evaluation of Herbicide-resistance status on populations of little seed canarygrass (Phalaris minor retz.) from southern Greece and suggestions for their effective control. J Plant Prot Res, 2012; 52(3): 314-18.
[18]Usman A, Elemo KA, Bala A, Umar A. Effect of weed interference and nitrogen on yields of a maize/rice intercrop. Int J Pest Manag, 2010; 47(4): 241-46.

[19]IITA. Multiple cropping. Retrieved from:www.iita. org/cms/details/trn-mat, 2007.

[20]Ferrero A, Scanzio $M$, Acutis M. Critical period of weed interference in maize. Proceedings of the $2^{\text {nd }}$ International Weed Control Congress, June 25-28, Copenhagen, Denmark, 1996; pp: 171-176.

[21]Carson AG. Weed competition and control in maize (Zea mays L). Ghana J Agric Sci., 2010; 9: 161-67.

[22] Kunjo I. An evaluation of the critical period and effect of weed competition on maize (Zea Mays) HD. Thesis College of Agriculture, Ahmadu Bello University Zaria Nig., 2011; pp. 65.

[23]Bakut HB. Effect of period of weed interference and weed control on maize-chilli pepper mixture. M.Sc Thesis Ahmadu Bello University Zaria. Nigeria, 2005; pp. 1212.

[24]Sohrab A, Ali K. Estimation of critical period for weed control in corn in Iran. Int Scholarly Scienti Res Innovation, 2009; 3(1): 27-32.

[25]Takim, FA, Fadayomi O. Influence of tillage and cropping systems on field emergence, Growth of weeds and yield of maize (Zea mays) and cowpea (Vigna ungu- iculata L.), AJAE, 2010; 1(4): 141-48.

[26]Scott RK, Wilcockson SJ, Moisey FR. The Effects of time of weed removal on growth and yield of Sugar beet. J Agri Sci Cambridge, 2011; 693-709.

[27]Nagaraju AP, Kumar HKM. Critical period of weed Interference in Soybean: Mysore. J Agri Sci., 2009; 43(1): 28-31. 